\title{
Social Security For Domestic Workers in Indonesia
}

\author{
$1^{\text {st }}$ Arinto Nugroho \\ Law Department, Faculty of Social \\ Sciences and Law \\ Universitas Negeri Surabaya \\ Surabaya, Indonesia \\ arintonugroho@unesa.ac.id
}

\author{
$2^{\text {nd }}$ Emmilia Rusdiana \\ Law Department, Faculty of Social \\ Sciences and Law \\ Universitas Negeri Surabaya \\ Surabaya, Indonesia \\ emmiliarusdiana@unesa.ac.id
}

\author{
$3^{\text {rd }}$ Mustari \\ Department of Pancasila and Civic \\ Education \\ Faculty of Social Science \\ Universitas Negeri Makassar
}

\begin{abstract}
Minister of Manpower Regulation Number 2 Year 2015 concerning Protection against Domestic Workers tries to protect domestic workers to get social security programs. Unfortunately, Article 11 letter (g) of this regulation only requires users to register domestic workers in social security programs without further explanation. This article creates confusion because there is no explanation about which type of social security that must be applied. The purposes of this study are to find out how the social security arrangements for domestic workers should be and the legal efforts that domestic workers can do in terms of not getting social security in Indonesia. This research is a normative juridical research with a statute approach. The results showed that the rule maker should put a clause about the type of social security that must be followed by domestic workers in the legislation. This could be the form of Law that has the advantage of being able to regulate the issuance of criminal sanctions but it takes a long time to enact the law. The second option is to include this type of social security in the amendment of the Minister Regulation which is fast to conduct changes but is not as strong as law because there will be no criminal sanctions. The legal remedies that can be conducted by domestic workers in case they are not included in the social security program are to make a lawsuit to the District Court on the basis of Default or Act Against the Law.
\end{abstract}

\section{Keywords - Social Security, Domestic Workers,}

\section{INTRODUCTION}

The Indonesian population growth rate has experienced a significant increase from year to year. The description of the growth rate from 1950 to 2015 can be seen in Table 1.1, as follows:

Table 1.1

Indonesian Population per 5 Years

\begin{tabular}{|c|c|c|c|c|}
\hline Year & Population & $\begin{array}{c}\text { Change } \\
(\%)\end{array}$ & Change & $\begin{array}{c}\text { Global } \\
\text { Rank }\end{array}$ \\
\hline 2015 & $258,162,113$ & $1.26 \%$ & $3,127,598$ & 4 \\
\hline 2010 & $242,524,123$ & $1.36 \%$ & $3,162,279$ & 4 \\
\hline 2005 & $226,712,730$ & $1.39 \%$ & $3,034,460$ & 4 \\
\hline 2000 & $211,540,429$ & $1.44 \%$ & $2,916,516$ & 4 \\
\hline 1995 & $196,957,849$ & $1.66 \%$ & $3,104,206$ & 4 \\
\hline 1990 & $181,436,821$ & $1.92 \%$ & $3,284,925$ & 4 \\
\hline
\end{tabular}

\begin{tabular}{|l|l|l|l|l|}
1985 & $165,012,196$ & $2.27 \%$ & $3,504,366$ & 4 \\
\hline 1980 & $147,490,365$ & $2.44 \%$ & $3,353,250$ & 4 \\
\hline 1975 & $130,724,115$ & $2.63 \%$ & $3,177,867$ & 5 \\
\hline 1970 & $114,834,780$ & $2.74 \%$ & $2,905,177$ & 5 \\
\hline 1965 & $100,308,894$ & $2.70 \%$ & $2,503,276$ & 6 \\
\hline 1960 & $87,792,515$ & $2.57 \%$ & $2,092,944$ & 6 \\
\hline 1955 & $77,327,794$ & $2.14 \%$ & $1,556,896$ & \\
\hline
\end{tabular}

Source: Statistics Indonesia

The increase in population growth and unavailability of employment will cause social problems, for instance, crime. In these unfavorable situations, job seekers try to find various types of work which sometimes are non-formal, one of them is domestic workers (PRT).

According to Article 1 number 1 of Minister of Manpower Regulation Number 2 Year 2015 concerning Protection against Domestic Workers, domestic workers are "people who work for individuals in the household to carry out domestic work by receiving wages and/or other forms of compensation". Employers who employ domestic workers are called users. Users, according to Article 1 number 3 of Minister of Manpower Regulation Number 2 Year 2015 concerning Protection against Domestic Workers, are "individuals who employ domestic workers by paying wages and/or other forms of compensation ". Both parties are mutually binding in a work agreement that can be conducted in writing or verbally.

Domestic workers have an important role in helping to facilitate the daily needs of a user. Users cannot freely work outside the home while at the same time they still have to do housework[1]. Indirectly, domestic workers also contribute to national development through increasing household income and increasing income tax due to the freedom to work outside the home. Focusing on the work without being disturbed by domestic affairs makes the user have a higher performance and in the end will get a commensurate reward[2]. High income automatically contributes to the State's income in the form of income tax that must be paid by each taxpayer in a country [3].

"Technology is fundamental to human welfare and social advancement, perhaps more so today where technological engagement is indispensable for participation in political, cultural, and economic processes"[4].In an era that relies 
heavily on technological devices, domestic workers are not only required to do ordinary household chores such as cleaning floors, sweeping, cooking with conventional stoves. Domestic workers are also required to master various skills in using the latest technology devices, such as the ability to drive a motorized vehicle when shopping at the market, cooking using a gas stove and using electronic devices that use electricity as an energy source and so on [5].

The complex job has put the domestic workers at high risk of doing so which results in injury or illness and can even end in death. [6] Based on this, it is necessary to create a mechanism that bears the risk if things happen that result in reduced and even lost domestic workers' income due to illness, work accident, job loss, old age or retirement called Social Security[7].

Article 34 number (2) of the Indonesian Constitution states that "The state develops a social security system for all people and empowers weak and incapable people in accordance with human dignity". This means that the state has provided a social security system for all people regardless of gender, religion, ethnicity and social status so that every citizen has the right to access social security, including domestic workers.

Important social security is needed by workers to ensure social and economic life is no exception for domestic workers [8]. Article 99 of Law Number 13 Year 2003 concerning Manpower (hereinafter referred to as UUK) states that "Every worker/laborer and his family has the right to obtain social security for workers." Although the UUK has become the legal basis of workers/laborers, in fact, it has not become an answer for legal protection of social security for domestic workers[9].

The International Labor Organization (hereinafter referred to as the ILO), is an international organization that fights for the rights of workers in the informal sector including domestic workers under the auspices of the United Nations. The ILO made ILO Convention No. 189 of 2011 concerning Decent Work for Domestic Workers[10]. This means that the problem of domestic workers is no longer a new problem but a legal problem in the world. The Convention was promulgated at the 100th annual ILO Conference which is a protection for domestic workers and provides a basis for recognition and guarantees that domestic workers get decent working conditions as workers in general[11].

The existence of ILO Convention No. 189 is not necessarily felt as legal protection for domestic workers because it has not been ratified through a system of formal legislation in Indonesia. Nevertheless, Indonesia has enacted UUK with which in Article 1 number (5) states that a worker is "Every person who works by receiving wages or other forms of rewards". From this article, it can be concluded that workers are both formal workers and informal workers.

Unfortunately, in labor law in Indonesia, workers are considered formal workers. Domestic workers are not employed in a formal company [5] so domestic workers in Indonesia are not considered as workers according to UUK. As a result, they have not been granted access to dispute resolution mechanisms as workers generally in the Industrial Relations Court established under Law Number 2 Year 2004 concerning the Settlement of Industrial Relations Disputes. (Hereinafter referred to as PPU Law). On the basis of this, domestic workers are not protected by laws such as other formal workers.[12]

An interesting breakthrough was made by the Indonesian Ministry of Manpower where on 19 January 2015 the Minister of Manpower issued Minister of Manpower Regulation No. 2 of 2015 concerning Protection of Domestic Workers. (Hereinafter referred to as Permenaker Number 2 of 2015 concerning PPRT). The enactment of the regulation makes domestic workers have legal certainty and clear legal status not only regarding social security but all that relates to its normative rights as workers in general. The application of the regulation provides evidence that the government is serious in considering the informal rights of domestic workers, including in the household sector, so that domestic workers are no longer considered slaves because their rights and obligations are clearly regulated. The rights and obligations of domestic workers are legally guaranteed including the right to social security. Article 11 letter (G) of the Minister of Manpower Regulation No. 2 of 2015 concerning PPRT states that "Users are obliged to include social security programs for domestic workers".

Looking at the article, there is a clear bright spot for protection for domestic workers in relation to social security. The problem is that if examined more deeply, the norm in the article is still multi-interpreted. This type of Social Security program according to Law Number 40 Year 2004 concerning the National Social Security System (hereinafter referred to as the SJSN Law), consists of health insurance, work accident insurance, old age insurance, pension insurance and life insurance. The organizing body that carries out the program is divided into 2, namely: the Health Social Security Organizing Body (BPJS Kesehatan) which deals with health insurance and the Manpower Social Security Organizing Body (BPJS Ketenagakerjaan) which deals with work accident insurance, pension insurance, pension insurance and life insurance.

Everyone, including foreigners who work at least 6 months in Indonesia are required to become social security participants as stated in Article 14 of Law Number 24 Year 2011 concerning Social Security Organizing Bodies (hereinafter referred to as UUBPJS). The obligation of registering workers for the social security program is then explained in more detail in Article 6 paragraph (2) of Presidential Regulation Number 109 Year 2013 concerning Stages of Participation in the Social Security Program (hereinafter referred to as PP Number 109 Year 2013) which contains "Employers other than state administrators in accordance with the scale of business referred to in paragraph (1) starting on 1 July 2015 must register their workers to the BPJS Ketenagakerjaan to participate in work accident insurance programs, old age insurance programs, pension guarantee programs, and life insurance programs gradually".

The obligation to register workers becomes a problem for PRT users because domestic workers are generally not a business entity [13], therefore the obligation to register workers for domestic workers is ambiguous. In case the user is equalized with a business entity, another problem also arises, which is related to the level of the business entity. As 
mentioned above, there are 3 business categories namely large and medium, small businesses and micro businesses. Each category has an obligation to register the type of social security. Equalizing domestic workers with micro businesses is certainly not right because it is very likely that domestic workers work in the homes of wealthy entrepreneurs whose monthly income exceeds micro-enterprises or even small businesses.[14]

Based on the above introduction, there are two problems that can be formulated. First, how should social security arrangements for domestic workers in Indonesia be? Second, what legal efforts can be made by domestic workers in terms of not getting social security in Indonesia.

\section{RESEARCH METHODS}

This study uses normative legal research or Doctrinal research which is "concerned with the formulation of legal 'doctrines' through the analysis of legal rules"[15]. The normative legal research uses secondary sources of law or materials obtained from library materials.[16] Based on the above explanation, the research is conducted by looking at library materials related to research objects such as norms or rules[17]. This study will describe in a logic analysis of Social Security for Domestic Workers in Indonesia.

This research uses a prescriptive analysis technique, "a technique which is intended to provide the arguments. The argument used to consider whether an action is correct or incorrect and/or what should it be based on the law". Furthermore, this research uses "statute approach in which the researcher uses regulation as the basis to analyze the data".[18]

The main formal sources of information for understanding the positive law used in this paper is in the form of primary and secondary sources.

\section{a. Primary sources of Law}

Primary sources of law are authoritative which mean the sources of law have the authority, which is the product of institution's activities. Primary sources of law here are norms or basic principles of law in Indonesia and some regulations that are relevant to this study, namely:

1. Indonesian Constitution;

2. Law Number 13 Year 2003 Concerning Manpower;

3. Law Number 2 Year 2004 concerning the Settlement of Industrial Relations Disputes

4. Law Number 40 Year 2004 concerning the National Social Security System

5. Law Number 24 Year 2011 concerning the Social Security Administering Body

6. Presidential Regulation Number 109 Year 2013 concerning Stages of Participation in the Social Security Program

7. Minister of Manpower Regulation Number 2 Year 2015 concerning Legal Protection of Domestic Workers

\section{b. Secondary Sources of law}

The secondary sources of law are the materials which are related to the primary sources of law. These will help explain and understand the primary sources of law. The secondary sources of law in this study are papers, journals, articles and news, the results of legal research, legal dictionary and encyclopedia of law relevant to this study, either printed or online.

\section{RESULTS AND DISCUSSION}

Based on the problems in the introduction section which consists of two legal issues, then this section will also be divided into 2 parts, namely: The Ideal social security arrangements for domestic workers in Indonesia and legal efforts that can be carried out in the event of not getting social security in Indonesia.

\section{A. The Ideal social security arrangements for domestic workers in Indonesia}

The provision that domestic workers are entitled to social security is a representation of human rights, which is a manifestation of the basic rights granted by God Almighty. The basic right is the right to get protection for social and economic life for domestic workers. The similarity before the law as stipulated in Article 34 paragraph (2) of Indonesian Consitution is the main foundation which is then re-stated in Minister of Manpower Regulation Number 2 Year 2015 concerning PPRT.

Article 11 letter (g) of Minister of Manpower Regulation Number 2 Year 2015 concerning PPRT, states that there is an obligation of domestic workers to include social security for their domestic workers. The phrase "obligatory" means something that must be done. On the other hand, this also means that social security is the right of domestic workers. The social security referred to in Minister of Manpower Regulation Number 2 Year 2015 concerning PPRT does not clearly regulate its type. It becomes a problem in the implementation of this obligation.

The types of social security in Indonesia according to Article 18 of the UUSJSN are health insurance, work accident insurance, old age insurance, pension insurance and life insurance. Health insurance is carried out by the Health Social Security Administering Agency (BPJS Kesehatan) while work accident insurance, old age insurance, pension insurance and life insurance are carried out by the Social Security Organizing Body (BPJS Ketenagakerjaan). The company is obliged to register its workers into social security as referred to in Article 6 paragraph (3) of PP Number 109 Year 2013, namely "Staging the registration as referred to in paragraph (2) for:

a. Large businesses and medium-sized businesses are obliged to join the work accident insurance program, old-age insurance program, pension insurance program, and life insurance program

b. Small businesses are obliged to join work accident insurance program, old-age insurance program and life insurance program

c. Micro businesses are obliged to join work accident insurance program and life insurance program. 
The obligations for employers are clearly stated in the PP Number 109 Year 2013 but not for domestic workers. PRT users are not business entities so they cannot be equated. Even if there are similarities, there is still unclear regarding which business level is the same as domestic workers.

To overcome this problem, the steps that must be taken are putting the registration and payment clauses of social security types that must be conducted by PRT users. This clause is important to make sure the type of the social security program for domestic workers. The regulation which can be adopted is Minister of Manpower Regulation Number 44 Year 2015 which put the clause regarding the rights of freelance Daily Workers in the field of construction to obtain work accident insurance and life insurance.

The step of regulating the rights of domestic workers in relation to social security can be done in two ways, namely by putting the clause in the Law concerning domestic workers and the second by making amendments to the Minister of Manpower Regulation concerning the Protection of Domestic Workers.

The choice to use the law is actually very reasonable. This is because the Act is hierarchically at the third level after the Indonesian Constitution and the Majelis Permusyawaratan Rakyat Decree. The Law will guarantee the force of the norm because this is a legal product produced by the Legislature and the executive. The application of the law also covers all Indonesian territory so that there will be uniformity of protection for domestic workers in Indonesia. In addition, lawmakers can also include criminal sanctions that function to provide a deterrent effect on perpetrators.

In addition to the benefits as mentioned above, drafting the law also has weaknesses. The most important thing is the process of making the law takes a long time. This is understandable because, in the sequence of drafting the law, it starts from the stipulation of the draft law in the National Legislation Program (Prolegnas). After being determined in the National Legislation Program, a bill cannot immediately be passed. One proof is the bill of the Protection of Domestic Workers. The bill was submitted in 2004 but, up to 14 years later it has not yet been enacted.

The House of Representatives has always had a different priority scale for 13 years since the proposed bill. The Protection of Domestic Workers bill has been included in the 2004-2009 Prolegnas period but the bill has only been included in the Prolegnas priority in 2010. The initial step to discuss was only carried out in 2011 by forming a working committee of The Protection of Domestic Workers Bill. The other step is the Secretariat General of the House of Representatives has to prepare the academic text and draft of the bill.

The change of government in 2014 made the Protection of Domestic Workers Bill was neglected until 2015. The decline actually happened in 2015 because the Commission IX abolished the Protection of Domestic Workers Bill from the priorities of the Prolegnas and replaced it with the Revised PPHI Law. The following year, the discussion of the Protection of Domestic Workers Bill was increasingly severe after restrictions on the number of bills discussed through the quota system.
With the limitation of 40 bills, both advanced and new, Commission IX can only discuss one to two new bills. The discussion of the 2016 Protection of Domestic Workers Bill is not a priority for the Prolegnas because the DPR prioritizes the Protection of Indonesian Workers Abroad bill which was finally passed in 2017.

The next option is to use the mechanism of an amendment to the Minister of Manpower Regulation Number 2 Year 2015 concerning PPRT. Amendments to the Minister of Manpower Regulation can be done relatively quickly because those who propose and authorize are executive body. Looking at Indonesia's long journey to protect domestic workers in the form of legislation that does not go ahead, making changes to the Manpower Ministerial Regulation is the right solution.

What needs to be remembered is that the protection of domestic workers embodied in the form of Minister Regulation has limitations on several matters. The first, the Minister Regulation is sectoral in nature, which means that everything that is regulated is limited to the Ministry of Manpower, whereas it is very possible that a legal action is mixed of interest with other ministries. The second weakness is related to criminal sanctions. As it is known together, in accordance with Article 15 paragraph (1) of Law Number 12 Year 2011 concerning the Establishment of Legislative Regulations, the contents of the criminal sanction can only be put in the Law, Province Regulations or Regency / City Regulations. From that fact, giving threats in the form of criminal sanctions cannot be put in the Minister of Manpower Regulation.

Based on this fact, if the objective is short-term and urgent, the norms concerning the types of social security that must be owned by domestic workers are regulated in an amendment to the Minister of Manpower Regulation. Furthermore, stakeholders must also constantly monitor the progress of the Protection of Domestic Workers Bill to ensure that the clause on the type of social security owned by domestic workers is included in it.

\section{B. The legal efforts that can be carried out by Domestic workers in the event of not getting social security in Indonesia.}

The relationship between employers and workers does not always work well. To resolve disputes between the parties, Indonesia already has a PPU Law. In Article 2 of this Law, the type of dispute consists of Rights Disputes, Interest Dispute, Disputes on Termination of Employment and Disputes between Trade Unions only in One Company. Stages of dispute resolution are arranged in such a way that begins with Bipartite Negotiations. If it has not been completed then proceed with a Tripartite negotiation mechanism involving the Conciliator, Arbitrator or Mediator. The last step that can be conducted if the dispute has not been completed is by proposing a lawsuit to the Industrial Relations Court which is a special court under the District Court.

In relation to domestic workers, disputes that occurred with PRT users could not be resolved using the PPU Law compliant mechanism. This is because domestic workers are not included in the category of workers as referred to in 
UUK. Therefore, in the event of a dispute then the aggrieved party will sue the users through the District Court on a basis of default or unlawful act.

The act of default in the promise or is commonly referred to as the Performance Act pursuant to Section 1238 of the Civil Code is "a condition due to negligence or fault, the debtor can not fulfill the performance as specified in the agreement". The form of not fulfilling can be: Not fulfilling performance at all, fulfilling performance but not timely, or fulfilling performance but inappropriate or incorrect.

To resolve the Default problem, the aggrieved party usually submits a written warning letter stating that the creditor wishes to fulfill the promise immediately or within the period specified in the notification. This is called Somasi. If the Somasi is not responded by an adverse party, the aggrieved party can file a lawsuit to the local General Court to get a judge's decision.

What must be considered for domestic workers who use the default as the basis in their lawsuit against the user who does not register in Social Security is that, the employment agreement, which is agreed upon before work, must include the obligation of the user to register domestic workers on Social Security.

In the event that there is no prior agreement between domestic workers and users regarding the registration of a social security, the step that domestic workers can take to obtain their rights is to sue to the District Court on the basis of Unlawful Act. It is considered unlawful if the act is contrary to the law in general. The law is not only in the form of legal provisions, but also unwritten legal rules, which must be adhered to in community life. The losses incurred must be caused by actions that violate the law; among others, losses and actions must have a direct relationship; the loss was caused by a manufacturer's mistake. The mistake is when the perpetrator is intentional or negligent.

As mentioned at the beginning of this paper, Article 11 letter (g) of the Minister of Manpower Regulation Number. 2 Year 2015 concerning PPRT requires users to include domestic workers in social security programs. This means that the user has the obligation to include domestic workers in the social security program, otherwise, then the user has committed an unlawful act.

The mechanism that can be carried out by domestic workers is almost similar to a lawsuit based on Default, ie. if there is no response from the user related to the objection of domestic workers because they are not included in the social security program, then domestic workers can file a lawsuit to the local district court

\section{CONCLUSION}

In essence, domestic workers in Indonesia are included as workers because they fulfill the elements of working on the other side, there are orders and there are wages but because they are included in informal work, domestic workers are not categorized as workers as intended by UUK. The consequence of this is that domestic workers do not get legal protection as workers generally include social security programs.
Minister of Manpower Regulation Number 2 Year 2015 concerning PPRT is a statutory regulation that tries to protect domestic workers to get a social security program, unfortunately, Article 11 letter (g) Minister of Manpower Regulation Number 2 Year 2015 concerning PPRT only requires users to include domestic workers in the social security program without further explanation. This article creates confusion because there are 5 types of social security, namely health insurance, work accident insurance, old age insurance, pension insurance and life insurance, and there is no clearly stated type of social security that must be followed by domestic workers

To overcome this problem, the lawmaker must put a clause about the type of social security that must be followed by domestic workers in the legislation. The first legislation is in the form of a law that has the advantage of being able to regulate criminal sanctions and a high level because it only exists under the Indonesian Constitution and the Majelis Permusyawaratan Rakyat Decree but takes a long time for approval. The second option is to include this type of social security in the amendment of the Minister of Manpower Regulation concerning Domestic Workers Protection. The advantage of this is that the time is relatively fast to make changes but the force is not as strong as the law.

In connection with legal remedies that can be conducted by domestic workers in the event that they are not included in the social security program, the domestic workers may make a lawsuit to the District Court on the basis of Default or Unlawful Act. The settlement through the Industrial Relations Court as referred to in the PPHI Law is not possible because domestic workers are not categorized as workers according to UUK.

\section{ACKNOWLEDGMENT}

The writer would like to express his gratitude to the Faculty of Social Sciences and Law, Universitas Negeri Surabaya for giving the opportunity to conduct the research as well as providing the fund to join the International Conference on Social Sciences 2018.

\section{REFERENCES}

J. Bernardino-Costa, "Intersectionality and female domestic workers' unions in Brazil," Womens. Stud. Int. Forum, vol. 46, no. C, pp. 72-80, 2014.

The Lancet, "Caring for migrant health-care workers," Lancet, vol. 390, no. 10110, p. 2325, 2017.

[3] G. Arrigo and G. Casale, Glossary of Labour Law and Industrial Relations. 2005.

[4] R. L. Okediji, "Law and Technology," Int. Encycl. Soc. Behav. Sci. Second Ed., vol. 13, pp. 520-527, 2015.

[5] K. Bosmans, S. Mousaid, N. De Cuyper, S. Hardonk, F. Louckx, and C. Vanroelen, "Dirty work, dirty worker? Stigmatisation and coping strategies among domestic workers," J. Vocat. Behav., vol. 92, pp. 54-67, 2016.

[6] B. Meehan, "The impact of licensing requirements on industrial organization and labor: Evidence from the U.S. private security market," Int. Rev. Law Econ., vol. 42, pp. 113-121, Jun. 2015.

[7] F. Cui, Y. Ge, and F. Jing, "The effects of the labor contract law on the Chinese labor market," J. Empir. Leg. Stud., vol. 10, no. 3, pp. 462-483, 2013. 
[8] Z. Ji-ying and W. Yao, "Investigation and Study on Employment Status of Migrant Workers in Heilongjiang Province," $J$. Northeast Agric. Univ. (English Ed., vol. 22, no. 1, pp. 83-90, 2015.

[9] T. I. Palley and R. M. LaJeunesse, "Social attitudes, labor law, and union organizing: Toward a new economics of union density," J. Econ. Behav. Organ., vol. 62, no. 2, pp. 237-254, 2007.

[10] ILO, “Labour Laws," Personnel, no. 1, pp. 1-24, 2013.

[11] D. S. Hamermesh, D. Kawaguchi, and J. Lee, "Does labor legislation benefit workers? Well-being after an hours reduction," J. Jpn. Int. Econ., vol. 44, pp. 1-12, 2017.

[12] K. O. P. I. I. U. Indonesia dan Timor Leste, Home-based workers: Decent work and social protection through organization and empowerment, Experiences, Good practices and lessons from home-based workers and their organizations, 1st ed. Jakarta: ILO, 2015.
[13] T. C. Vigtel, "The retirement age and the hiring of senior workers," Labour Econ., vol. 51, no. February, pp. 247-270, 2018.

[14] C. Van der Elst, "Industry-specificities and size of corporations: determinants of ownership structures," Int. Rev. Law Econ., vol. 24, no. 4, pp. 425-446, Dec. 2004

[15] P. Chynoweth, "Legal Research," in Advanced Research Methods in the Built Environment, 2008, pp. 27-38.

[16] I. J. Kroeze, "Legal Research Methodology and the Dream of Interdisciplinarity.," Potchefstroom Electron. Law J., vol. 16, no. 3, pp. 35-65, 2013.

[17] P. Langbroek, K. Van Den Bos, M. S. Thomas, M. Milo, and W. Van Rossum, "Methodology of Legal Research: Challenges and Opportunities," Utr. Law Rev., vol. 13, no. 3, pp. 1-8, 2017.

[18] P. M. Marzuki, Penelitian Hukum, 11th ed. Jakarta: Kencana, 2011. 